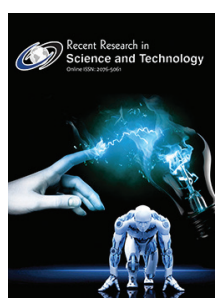

ISSN: 2076-5061
Received: February 02, 2018 Accepted: April 27, 2018 Published: May 05, 2018

*Corresponding Author: AO Akinpelu Email: immadipo@yahoo.com

\section{Market level characteristic factors influencing smallholder coffee marketers in Kogi State, Nigeria}

\author{
A. O. Akinpelu'*, A. F. Okunade ${ }^{2}$ and K. A. Oluyole ${ }^{1}$
}

'Department of Economics and Extension, Cocoa Research Institute of Nigeria (CRIN), Idi Ayunre, Ibadan, Oyo State, Nigeria, ${ }^{2}$ Central Processing Unit, Cocoa Research Institute of Nigeria (CRIN), Idi Ayunre, Ibadan, Oyo State, Nigeria

\begin{abstract}
The study assessed the market level characteristic factors influencing coffee marketing among coffee farmers in the study area. The study was carried out in Kogi State and purposive sampling technique was used to select eighty four respondents. Data were collected from the respondents with the use of structured questionnaire and the data collected were analyzed using descriptive statistics (frequency and percentages) as well as multi-variate regression analysis. Result of the descriptive analysis shows that the mean age of the farmers was 64 years while $60 \%$ of the farmers had no access to formal education. Regression analysis revealed that farm size, variety of coffee, marketing channels, trading experience, membership of association, price satisfaction and selling method constituted major characteristic marketing factors influencing coffee marketing in the study area and they all affected coffee marketing at $1 \%$ significant level. Based on the findings, the study therefore recommended that efforts should be made to assess variety of coffee that is more preferred by the buyers. Also, farmers should be given incentives to increase their farm holdings for higher productivity.
\end{abstract}

KEYWORDS: Coffee, marketing, cobb douglas, Variety, policies

\section{INTRODUCTION}

Coffee is used throughout the world and is being brought to most of the countries during colonial period itself. Coffee became a cash crop and provided labor to many people in developing countries [1]. Many of the countries are suitable for coffee production and the agricultural sector supported its planting [2]. One of the previous studies [3] explained the growth habits and ideal conditions for growing coffee plants. Different types like Coffea Arabica and Coffea Robusta are in used in almost all countries [3].

The farmers of these beans are usually small scale producers. Many studies showed that these farmers produce the business sectors [4-11]. The marketing issue and constraints are always a problem for these small holders. The objectives of the study were to profile the socio economic characteristics of the traders (farmers), factors that determine coffee marketing and identification of problems militating against coffee marketing in the study area.

\section{METHODOLOGY}

The study was conducted in Kogi State, Nigeria. The state is in the middle belt region and falls in to the guinea savannah agro ecological zone of the country. Two Local Government Areas (Ijumu and Kabba-Bunu Local Government Areas) were purposively sampled. These areas are known for the cultivation of coffee in Kogi State. A total sample of eighty four respondents was used. Structured interview schedules were used for data collection from respondents. Data were collected on socio economic characteristics (Age, Educational Status, Marital Status, Gender, Membership of Farmers' Group) and market level characteristics (Farm size, Trading Experience, Coffee Variety, Marketing Channel, Membership of farmers' Group, Price Satisfaction, Selling Methods) respectively. Additional information was gathered through informal discussions with the farmers and by personal observations of the crop in some of the farmers' fields. Data were analyzed using descriptive statistics (frequency and percentages), and multiple regression analysis. The Cobb Douglas (Double Log) regression model was chosen based on the value of the $\mathrm{R}^{2}$ and the number of significant variables. The model is described explicitly thus:

$$
\begin{aligned}
\log Y= & \beta_{0}+\beta_{1} \log X_{1}+\beta_{2} \log X_{2}+\beta_{3} \log X_{3}+\beta_{4} \log X_{4}+\beta_{5} \log X_{5} \\
& +\beta_{6} \log X_{6}+\beta_{7} \log X_{7}+e_{i}
\end{aligned}
$$

Where $\mathrm{Y}=$ yield of coffee $(\mathrm{kg} / \mathrm{ha})$

$\mathrm{X}_{1}=$ selling method (years)

$\mathrm{X}_{2}=$ trading experience (years)

Copyright: () 2018 The authors. This article is open access and licensed under the terms of the Creative Commons Attribution License (http://creativecommons.org/licenses/by/4.0/) which permits unrestricted, use, distribution and reproduction in any medium, or format for any purpose, even commercially provided the work is properly cited. Attribution - You must give appropriate credit, provide a link to the license, and indicate if changes were made. 
$\mathrm{X}_{3}=$ marketing channel ( $1=$ local buying agents, $0=$ exporters $)$

$\mathrm{X}_{4}=$ farm size (hectares)

$\mathrm{X}_{5}=$ membership of cooperative society $(1=$ yes, $0=$ no $)$

$\mathrm{X}_{6}=$ variety of coffee $(1=\mathrm{C}$. Arabica, $0=\mathrm{C}$. Robusta $)$

$\mathrm{X}_{7}=$ price satisfaction $(\mathrm{N} / \mathrm{Kg})$

$\mathrm{e}_{1}=$ error term

\section{RESULTS AND DISCUSSION}

Table 1 shows the socio-economic characteristics of coffee farmers. The table reveals that all the farmers (100\%) were men. This result is in conformity with [12] who reported that majority (94.4\%) of groundnut farmers were male. Similarly, [13] reported that in Africa, men are more in a crop that is perceived to have commercial value. The implication of this is that coffee trading in the study area is largely dominated by male gender. Moreover, the mean age of the farmers was 64 years. The implication of this is that coffee farmers in the state are ageing and almost out of their productive years and this perhaps may be responsible for the average farm size (5ha) put into cultivation of the crop by farmers in the study area. Similarly, the table reveals that about $60 \%$ of the farmers had no access to former education with average years of educational level being about 2 years. The implication of this is that the farmers may perhaps not have access to information with respect to both production and marketing of the crop. Furthermore, the table reveals an average household size of 8 persons. This implies that the farmers may perhaps utilize members of the household as labour for some operations relating to production and marketing of the crop. This may reduce some transaction costs that may be incurred on the crop. Mean trading experience was about 29 years. This means that the farmers have adequate knowledge of marketing the crop. This may influence the choice of marketing channels as the farmers sell to preferred buyers.

Table 2 shows the market level characteristic factors influencing marketing of coffee among smallholder farmers. The table reveals that farm size of the farmers was highly significant at $1 \%$ level of probability with positive coefficient. The implication of this is that the larger the farm size, the higher the quantity of coffee available to the farmers for marketing (Ceteris paribus). This conforms to a priori expectation. It is expected that as farm size increases the farmers tend to sell more to buyers. In addition, the table reveals that price satisfaction and selling method respectively are highly significant at $1 \%$ level of probability. This implies that there is perhaps a mutual understanding between the farmers and the preferred buyers. Similarly, positive coefficient of the selling method as presented in the table implies that the farmers are more comfortable with the method adopted in selling the crop. This means that the more they sell to local buyers the more profit they tend to make. Furthermore, variety of coffee traded is significant $(\mathrm{p} \leq 0.01)$ but with negative value. The implication of this is that the buyers may perhaps have preferred variety among the two coffee varieties available in the study area. Also, the table reveals that the marketing channel was significant $(\mathrm{p} \leq 0.01)$ but negative coefficient. This perhaps means that not all the farmers may be satisfied with the available channels through which the commodity is been marketed.
Table 1: Socio economic characteristics of Coffee Farmers in Kogi State

\begin{tabular}{|c|c|c|c|}
\hline Variables & Frequency & Percentage (\%) & Mean \\
\hline \multicolumn{4}{|l|}{ Sex } \\
\hline Male & 84 & 100.00 & \\
\hline Female & 00 & 00.00 & \\
\hline Total & 84 & 100.00 & \\
\hline Age (Years) & & & 64 \\
\hline $50-59$ & 20 & 24.00 & \\
\hline $60-69$ & 32 & 38.00 & \\
\hline 70 and Above & 32 & 38.00 & \\
\hline Total & 84 & 100.00 & \\
\hline \multicolumn{4}{|l|}{ Marital Status } \\
\hline Married & 76 & 90.00 & \\
\hline Widowed & 8 & 10.00 & \\
\hline Total & 84 & 100.00 & \\
\hline Education (No of years) & & & 2 \\
\hline No Education & 52 & 60.00 & \\
\hline Primary & 8 & 10.00 & \\
\hline Secondary & 8 & 10.00 & \\
\hline Tertiary & 16 & 20.00 & \\
\hline Total & 84 & 100.00 & \\
\hline \multicolumn{4}{|l|}{ Membership of Farmers'Group } \\
\hline Yes & 64 & 76.00 & \\
\hline No & 20 & 24.00 & \\
\hline Total & 84 & 100.00 & \\
\hline Household Size (No. of Persons) & & & 8 \\
\hline $1-5$ & 20 & 24.00 & \\
\hline $6-10$ & 44 & 52.00 & \\
\hline Above 10 & 20 & 24.00 & \\
\hline Total & 84 & 100.00 & \\
\hline Farm Size (Hectares) & & & 5 \\
\hline $1-5$ & 40 & 48.00 & \\
\hline $6-10$ & 44 & 52.00 & \\
\hline Total & 84 & 100.00 & \\
\hline Trading Experience (Years) & & & 29 \\
\hline $10-29$ & 44 & 52.00 & \\
\hline $30-49$ & 36 & 43.00 & \\
\hline Above 50 & 4 & 5.00 & \\
\hline Total & 84 & 100.00 & \\
\hline \multicolumn{4}{|l|}{ Marketing Channel } \\
\hline Local Buying Agents & 68 & 81.00 & \\
\hline Exporters & 16 & 19.00 & \\
\hline Total & 84 & 100.00 & \\
\hline \multicolumn{4}{|l|}{ Coffee Variety } \\
\hline C. Arabica & 20 & 24.00 & \\
\hline C. Robusta & 64 & 76.00 & \\
\hline Total & 84 & 100.00 & \\
\hline
\end{tabular}

Source: Field Survey, 2016

There may be need for more stakeholders' involvement in the marketing channels available in the area. Moreover, the trading experience is also highly significant $(\mathrm{p} \leq 0.01)$ but with negative coefficient. This is contrary to a priori expectation. Also, this result is contrary to [11] who reported a non-significance value for trading experience on coffee marketing in Ethiopia. It is expected that the more the years of trading will result in more years of knowledge of selling the commodity. However, the result showed that the lower the years of trading in the crop, the lower the experience of the farmers.

Table 3 showed the result of the test for multicollinearity. Variance Inflation Factor (VIF) showed how multicollinearity has increased the instability of the coefficient estimates [14]. The result showed no problem of multicollinearity since the 
Table 2: Market Level Factors Influencing Coffee Marketing among Smallholder Farmers

\begin{tabular}{lccc}
\hline Variable & Coefficient & $\begin{array}{c}\text { Std. } \\
\text { Error }\end{array}$ & t-Value \\
\hline Farm size of respondents & 1.4496 & 0.1671 & $8.67 * * *$ \\
Variety of Coffee & -3.1418 & 0.3612 & $-8.70^{* * *}$ \\
Marketing channels & -0.6605 & 0.2238 & $-2.95^{* * *}$ \\
Trading experience & -1.1171 & 0.1768 & $-6.32 * * *$ \\
Membership of Association & -0.8693 & 0.3823 & $-2.27 * * *$ \\
Price satisfaction & 0.6079 & 0.2728 & $2.23 * * *$ \\
Selling Method & 0.6028 & 0.2827 & $2.13 * * *$ \\
Constant & 2.2128 & 0.2840 & $7.79 * * *$ \\
R & 0.6035 & & \\
Adjusted R & 0.5670 & & \\
Number of Observation & 84 & & \\
\hline
\end{tabular}

Source: Field Survey, 2016; ***,**,*, Significant at 1\%, 5\% and $10 \%$ level of Probability

Table 3: Result for test of Multicollinearity

\begin{tabular}{lcc}
\hline Variable & VIF & I/VIF \\
\hline Farm size of respondents & 3.74 & 0.27 \\
Variety of Coffee & 3.81 & 0.26 \\
Marketing channel & 1.24 & 0.80 \\
Trading experience & 2.02 & 0.49 \\
Membership of Association & 4.27 & 0.23 \\
Price satisfaction & 1.85 & 0.54 \\
Selling method & 1.58 & 0.63 \\
Mean VIF & 2.64 & \\
\hline
\end{tabular}

Source: Field Survey, 2016

Variance Inflation Factor (VIF) values of the variables in the model are less than the critical value (10). The estimated VIF results range from 1.24 to 3.81 with a mean value of 2.64. This showed that multicollinerity is not an issue in the model as these values for the explanatory variables are less than 10 . The result is similar to [15], [16] and [17] who reported a VIF of less than 10.

\section{CONCLUSION AND RECOMMENDATIONS}

The study assessed market level characteristic factors influencing coffee marketing in Kogi State. Farm size, variety of coffee, marketing channel, trading experience, membership of association, price satisfaction and selling method constituted market level characteristic factors influencing coffee marketing in the study area. More efforts should be made to assess variety of coffee that is more preferred by the buyers. In addition, farmers should be trained on the variety of the crop that has higher market demand with a view to increase its production in the study area. Similarly, farmers should be given incentives to increase their farm holdings for higher productivity. In addition, there is a need to maintain or improve on the price satisfaction existing between the farmers and the buyers of the commodity to avoid imperfect market in the study area. Farmers that are members of association should be encouraged to improve on their participation as this will go a long way in price determination for increased profit. This will encourage and improve coffee traders' access to market information and as such will be able to sell the crop for more profits.

\section{REFERENCES}

1. James D. Coffee in a Fair Trade Market. Report on the Americas. 2000; 11-14.

2. Cleland D. The Impacts of Coffee Production on Local Producers. Social Sciences Department College of Liberal Arts. California Polytechnic State University. 2010.

3. Milford A. Coffee, Co-operatives and Competition: The Impact of Fair Trade. Chr. Michelsen Institute. Development Studies and Human Rights. 2004.

4. Kersting S, Wollni M. New institutional arrangements and standard adoption: Evidence from small-scale and vegetable farmers in Thailand. Food Policy 2012; 37:452-462.

5. Wollni M, Zeller M. Do farmers benefit from participating in specialty markets and Cooperatives? The case of Coffee Marketing in Costa Rica, Agricultural Economics. 2007; 37: 243-248.

6. Gruere G, Nagarajan L, King E. The Role of Collective Action in the Marketing of Underutilized Plant Species: Lessons from a case study on minor millets in South India, Food Policy. 2009; 34: 39-45.

7. Devaux A, Horton D, Velasco C, Thiele G, Lopez G, Bernet T, Reinoso I, Ordinola M. Collective action for market chain innovation in the Andes, Food Policy. 2009: 34:31-38.

8. Narrod C, Roy D, Okello J, Avendano B, Rich K, Thorat A. PublicPrivate Partnerships and Collective action in high value Fruit and Vegetable supply chains, Food Policy. 2009; 34:8-15.

9. Ponte S, The "Latte Revolution"? Regulation, Markets and Consumption in the Global Coffee Chain. World Development. 2002;30(7): 1099-1122.

10. Jena PR, Stellmacher T, Grote U. The Impact of Coffee Certification on Small-Scale Producers' Livelihoods: Evidence from Ethiopia. Selected Paper prepared for presentation at the International Association of Agricultural Economists (IAAE) Triennial Conference, Foz do Iguaçu, Brazil, 2012; 18-24 August.

11. Anteneh A, Muradian R, Ruben R. Factors Affecting Coffee Farmers Market Outlet Choice. The Case of Sidama Zone, Ethiopia. Paper prepared for the EMNet 2011 in Cyprus. 2011; Dec. 1 - 3.

12. Adinoyi A, and Attanda MI. Determination of Farm Holding Capacity of Groundnut Farmers in Kano State, Nigeria. Proceedings of the $50^{\text {th }}$ Annual Conference of Agricultural Society of Nigeria. Held at the Library Complex, National Root Crops Research Institute, Umudike, Abia State from $3^{\text {rd }}-7^{\text {th }}$ October, 2016;:74-78.

13. Girei AA, Daura Y, and Dire B. An Economic Analysis of Groundnut (Arachis hypogaea) Production in Hong Local Government Area of Adamawa State, Nigeria. Journal of Agricultural and Crops Research. 2013; Vol. 1 (6):84-89.

14. Freund, RJ, and Ramon C. Littell. 2000. SAS System for Regression (Third edition). Cary, NC: SAS Institute.

15. Osman MAA. Analysis of Factors Influencing Women's Decision to Adapt to Climate Change: The Case of Rural Women in Haramaya District, Eastern Ethiopia. An Msc. Thesis submitted to the School of Natural Resources and Environmental Sciences, School of Graduate Studies, Haramaya University, Ethiopia; 2015.

16. Kleinbaum D, Kupper L, Nizam A, Rosenberg KS. Applied Regression Analysis and Other Multivariable Methods. 2014; $5^{\text {th }}$ Ed, Cengage Learning.

17. Tazeze A, Haji J, and Ketema M. Climate Change Adaptation Strategies of Smallholder Farmers: The Case of Babilie District, East Harerghe Zone of Oromia Regional State of Ethiopia. Journal of Economics and Sustainable Development. 2012; (3)14. www.iiste.org 